\title{
Determinants of Birth Asphyxia Among Newborns in Referral Hospitals of Amhara National Regional State, Ethiopia
}

This article was published in the following Dove Press journal: Pediatric Health, Medicine and Therapeutics

\section{Alemwork Desta Meshesha $\mathbb{D}^{1}$ Muluken Azage $\mathbb{I D}^{2}$ \\ Endalkachew Worku ${ }^{3}$ Getahun Gebre Bogale ${ }^{4}{ }^{4}$}

'ART Clinic, Dessie Referral Hospital, Dessie, Amhara Regional State, Ethiopia; ${ }^{2}$ Department of Environmental Health, School of Public Health, College of Medicine and Health Sciences, Bahir Dar University, Bahir Dar, Ethiopia; ${ }^{3}$ Department of Reproductive Health and Population Studies, School of Public Health, College of Medicine and Health Sciences, Bahir Dar University, Bahir Dar, Ethiopia; ${ }^{4}$ Department of Health Informatics, College of Medicine and Health Sciences, Wollo University, Dessie, Ethiopia
Correspondence: Getahun Gebre Bogale P.O. Box: 1145

Tel +251914715992

Email getahungebre2I@gmail.com

Alemwork Desta Meshesha

P.O. Box: 15478

Tel +251914614994

Email alemworkd2I@gmail.com
Background: Globally, every year, 2.5 million infants die within their first month of life. Birth asphyxia is one of the leading causes in all low- and middle-income countries and the leading single cause of neonatal mortality in Ethiopia. Therefore, the aim of this study was to identify the determinants of birth asphyxia among newborns admitted to neonatal intensive care units (NICU) in Amhara region referral hospitals, Ethiopia.

Methods: Facility-based unmatched case-control study was employed from March 1 to April 30, 2018. Cases were newborn babies admitted to neonatal intensive care units with an admission criteria of birth asphyxia with APGAR score of $<7$ at five min of birth and controls were newborn babies admitted to NICU with an admission criteria of other complications (such as jaundice, congenital anomalies, sepsis, hemorrhagic diseases) with APGAR score of $\geq 7$ at five min of birth. Using SPSS version 20, bivariate logistic regression model was fitted to check the relation of each independent variable to the outcome variable. Variables with $p<0.2$ in bivariate analysis were transferred to multivariable logistic regression model for final analysis. Variables with an adjusted odds ratio (AOR) of $95 \% \mathrm{CI}$ and $p<0.05$ were reported as determinants of birth asphyxia.

Results: Data were collected from 193 cases and 193 controls with a response rate of $100 \%$. Low birth weight (AOR: 8.94, 95\%CI: 4.08, 19.56), born at health centers (AOR: 7.36, 95\% CI: 2.44, 22.13), instrumental delivery (AOR: 3.03, 95\%CI: 1.41, 6.49), and prolonged labor (AOR: 2.00, 95\%CI: 1.20, 3.36) were significant determinants of birth asphyxia.

Conclusion: Even though most of the identified variables are the common and familiar causes of birth asphyxia, neonates born at health centers were more exposed to birth asphyxia than neonates born in hospitals. This might be due to delay of referral process and lack of skilled professionals in health centers. Further research might be needed to identify the root causes of delays and follow-up issues by adding qualitative component.

Keywords: birth asphyxia, cases, controls, case-control

\section{Introduction}

Birth asphyxia is a condition characterized by an impairment of exchange of the respiratory gases resulting in hypoxemia and hypercapnia, accompanied by metabolic acidosis. ${ }^{1}$ It is defined by the World Health Organization as "the failure to initiate and sustain breathing at birth". ${ }^{2}$ Newborns are vulnerable to illnesses and deaths during the postnatal period. ${ }^{3}$ Birth asphyxia is one of the leading causes of neonatal mortality in low and middle-income countries and it is also the main cause of long-term illnesses including mental retardation, cerebral palsy, and other neurodevelopmental disorders. 4 
Worldwide, 2.5 million infants die within their first month of life every year, contributing nearly $47 \%$ of all deaths of children under five year's of age. Almost all deaths of newborns are in developing countries, with the highest number in South Asia and sub-Saharan Africa. ${ }^{5}$ International reports indicated that birth asphyxia is the third cause of neonatal deaths next to infections and preterm. ${ }^{6}$ Each year, $24 \%$ of neonatal deaths occurred due to birth asphyxia. ${ }^{7,8}$ Studies done in Columbia, ${ }^{9}$ Nigeria, ${ }^{10}$ and southwest Ethiopia ${ }^{11}$ indicated that the prevalence of birth asphyxia were about $41 \%, 21 \%$, and $12.5 \%$, respectively.

Ethiopia is one of the 10 countries with the highest number of neonatal mortality worldwide, with an estimated number of 122,000 newborn deaths per year. ${ }^{12}$ Nationally, birth asphyxia contributed $24 \%$ of neonatal deaths. ${ }^{13}$

Studies conducted in Thailand, Pakistan and Ethiopia indicated that low birth weight, caesarian section; ${ }^{14-16}$ multiple births, lack of antenatal care; ${ }^{17}$ maternal age, gravidity, and mode of delivery; ${ }^{18}$ prolonged labor, and fetal distress ${ }^{16}$ were significant causes of birth asphyxia. However, unlike to this study, most of the studies were conducted at individual facility level which may not able to reflect the shared regional burden. Additionally, they used secondary data sources which may face to data / information incompleteness. Therefore, the aim of this study was to identify significant determinants of birth asphyxia among newborns at region level for formulating intervention mechanisms at local, regional and national levels.

\section{Methods}

\section{Study Design, Period and Setting}

Facility-based unmatched case-control study was employed to identify the determinants of birth asphyxia among newborns in referral hospitals of Amhara national regional state, Ethiopia from March 1 to April 30, 2018.

The Amhara National Regional State is located in the northwestern part of Ethiopia between $9^{\circ} 20^{\prime}$ and $14^{\circ} 20^{\prime}$ north latitude and $36^{\circ} 20^{\prime}$ and $40^{\circ} 20^{\prime}$ east longitude. The Central Statistics Agency's total population projection estimate for the Amhara Region for 2017 is 21,134,988 with a fifty-fifty numerical split between the sexes. Of these $17 \%$ were urban residents which are below the national average. ${ }^{19}$ According to Ethiopian 2009 Ethiopian Fiscal Year Annual Performance Report published by Federal Ministry of Health, Amhara has 68 Hospitals, 841 Health
Centers and 3342 Health Posts. ${ }^{20}$ Among the 68 functional hospitals in the region, Dessie, Felege-Hiwot, University of Gondar, Debebirhan, and Debremarkos hospitals are tertiary care (referral) hospitals. Thus, all five referral hospitals serve the population found in the region.

\section{Study Participants}

All asphyxiated and nonasphyxiated newborns admitted to neonatal intensive care units (NICU) of referral hospitals found in Amhara regional state were the study population. Cases were newborn babies admitted to NICU with an admission criteria of birth asphyxia (APGAR score of $<7$ at five min of birth) from cohort of mother-newborn pairs. Controls were newborn babies admitted to NICU with an admission criteria of other complications such as jaundice, congenital anomalies, sepsis, hemorrhagic diseases (but APGAR score of $\geq 7$ at five min of birth) from their own cohort of mother-newborn pairs. Newborn babies who had no mothers (caregivers) due to lost or death and mothers who were sick and unable to respond were excluded from the study.

\section{Sample Size and Sampling Procedures}

Sample size was calculated based on unmatched case-control formula (Kelsey) with the assumptions of power $=80 \%$ and 95\%CI using Epi Info version 7. From previous case-control studies on determinants of birth asphyxia, the major determinants were low birth weight $(p=11.33 \%, \mathrm{OR}=2.40$ ), gestational age of $<37$ weeks ( $p=52 \%, \mathrm{OR}=2.57$ ), multiple births ( $p=6.2 \%$, $\mathrm{OR}=0.11)$, mode of delivery $(p=22.2 \%, \mathrm{OR}=2.94)$, and gravidity $(p=33.3 \%, \mathrm{OR}=2.64) .{ }^{14,18,21}$ From the alternative sample sizes, the largest sample size (386; 193 cases and 193 controls) was selected. Recently, these five hospitals are evenly distributed geographically while the sample sizes were selected after proportional allocation to their respective hospitals. They have their own NICU. Among the estimated total admissions, 2091 newborns, in the study period, 193 newborns with birth asphyxia and 193 newborns without birth asphyxia were selected for the study. After proportional allocation to their respective hospitals, systematic random sampling technique was employed to select every second asphyxiated newborns and every eighth non-asphyxiated newborn during data collection period.

\section{Operational Definitions}

Birth asphyxia is the failure to initiate and sustain breathing at birth. Appearance Pulse Grimace Activity Respiration (APGAR) Score of $<7$ (asphyxiated newborn which shows either not able to breath after birth and convulsions/spasms or 
not able to suckle normally after birth or not able to cry after birth). ${ }^{2}$ Preeclampsia/eclampsia is a condition that can develop during pregnancy characterized by high blood pressure (hypertension) and protein in the urine (proteinuria). If not properly recognized and managed, preeclampsia can progress to eclampsia, which is defined as the development of seizures in a woman with preeclampsia. Prolonged labor, also known as failure to progress, was considered when the labor, after the latent phase of first stage of labor, exceeds 12 hours in primigravida or 8 hours in multipara mothers. ${ }^{22-24}$ Premature rupture of membrane (PROM) was considered as a rupture of the membrane of the amniotic sac and chorion occurred more than one hour before the onset of labor. Prolonged rupture of membrane is a rupture of membrane or leaking for $>18$ hours.

\section{Data Collection Tools, Procedures and Data Quality Control}

A pre-tested structured interviewer-administered questionnaire and checklist were used for data collection. Both tools were prepared in English language and the questionnaire was translated to local language, Amharic, and then translated back to English language to check inconsistency. The English version checklist was used to review maternal medical records which were written in English language. The questionnaire was used to collect data on maternal sociodemographic and behavior-related variables, such as age, marital status, residence, education, occupation, income, khat chewing, and alcohol drinking. Whereas, the checklist was used to review maternal health-related variables (such as, preeclampsia/eclampsia, HIV status, diabetes mellitus, bleeding in pregnancy, irondeficiency anemia, referral status), antepartum-related variables (such as, gravidity, parity, multiple birth, number and place of antenatal care visits), intrapartum related variables (such as, prolonged labor and rupture of membrane, premature rupture of membrane, fetal presentation, and mode of delivery), and newborn-related variables (such as, sex, birth weight, asphyxia status and gestation age) from medical records of mother-newborn pairs.

Ten professional nurses were trained for data collection and supervision. To prevent expected biases, five of them were data collectors who had previous experiences of pediatric wards in other hospitals and but not working recently in the pediatric wards/NICU at the time of data collection. The five supervisors who had previous experiences of pediatric wards were from the nearby universities. The questionnaire was pretested in $5 \%$ of clients and possible modifications were made prior to data collection. The supervisors and the principal investigator supervised the data collection process. They followed and checked data consistency, completeness, clarity and accuracy throughout the data collection process. They also supported data collectors in filling their gaps to achieve the goal of data collection.

\section{Data Analysis}

Data were edited, coded and entered to Epi info version 7 software packages and exported to Statistical Package for Social Sciences (SPSS) version 20 (IBM Corporation, Armonk, NY, USA) for analysis. After missing data were removed, descriptive analysis was performed to calculate means with standard deviations, frequencies, and percentages. Bivariate logistic regression analysis was done to check the association of each independent variable to the outcome variable. At this stage, based on experts' recommendations specified for if $\geq 20$ covariates, a cut-off $p<0.2$ was used to screen candidate variables for the final model. Hosmer and Lemeshow goodness of fit test was used to check model fitness. Finally, the screened variables were fitted to multivariable logistic regression model through backward stepwise method to reduce the effects of confounders. Adjusted odds ratio with $95 \% \mathrm{CI}$ and $p<0.05$ used to declare significant determinants of birth asphyxia.

\section{Ethics Approval and Consent to Participate}

Ethical clearance was obtained from the ethical review board (protocol number 009/18-01) of School of Public Health, College of Medicine and Health Sciences, Bahir Dar University. The ethical review board approved that oral informed consent, and consent from participants under the age of 18 years were included. Permission was obtained from Amhara public health institute and five referral hospitals. Full explanation of the study was given to respondents and oral informed consent was obtained from the study participants. Confidentiality of data was maintained anonymously.

\section{Results}

\section{Sociodemographic and Behavioral Characteristics}

A total of 386 (193 cases and 193 controls) participants were involved in the study with a response rate of $100 \%$. Maternal mean $( \pm$ S.D.) age was $26.63( \pm 5.09)$ years. Among the total study groups, $109(56 \%)$ of cases and $105(54 \%)$ of controls were in the age group of 25-34 
years. Majority of respondents, $182(94 \%)$ of cases and 170 (88\%) of controls, were married. More than half of the respondents; $103(53 \%)$ of cases and $121(63 \%)$ of controls, came from urban areas. Housewives and farmers constituted $133(69 \%)$ of cases and 101 (52\%) of controls. Sixty-three (33\%) of cases and 53 (28\%) of controls were at elementary school (1-8 grades). One hundred thirteen (59\%) of cases and 95 (49\%) of controls had less than 2000 Ethiopian Birr monthly incomes. Most of the cases and controls were come to hospitals from the nearby areas. All respondents were nonsmokers. Majority of cases and controls, 374 (97\%), had not ever chewed khat. However, $62(32 \%)$ of cases and $65(34 \%)$ of controls drank alcohol during the last pregnancy (Table 1).

\section{Maternal Health Related Variables}

Majorly 173 (90\%) of cases and 177 (92\%) of controls did not faced preeclampsia/eclampsia, however, $20(10 \%)$ of cases and $16(8 \%)$ of controls faced the problem. Eight (4\%) of cases and $9(5 \%)$ of controls have HIV. Twentytwo (9\%) of cases and $14(7 \%)$ of controls faced bleeding during the most recent pregnancy. Forty-four (23\%) of cases and $32(17 \%)$ of controls had iron-deficiency anemia. One hundred twenty-four (64\%) of cases and 89 (46\%) of controls were referred from another health facilities (Table 2).

\section{Antepartum and Intrapartum Related Variables}

Among the total respondents, 91 (47\%) of mothers with cases and $105(54 \%)$ of mothers with controls experienced more than one pregnancy, however, $102(53 \%)$ of cases and 88 $(46 \%)$ of controls experienced their first pregnancy. Of the study units, 84 (44\%) of cases and 96 (50\%) of controls; and $109(57 \%)$ of cases and 97 (50\%) of controls were multiparous and primiparous respectively. Five (2.6\%) of the cases and 16 $(8.3 \%)$ of controls had given birth to twins during the most recent pregnancy. Nearly 189 (98\%) of cases and 188 (97\%) of controls had antenatal care (ANC) visits. Of the total respondents, 88 (46\%) of cases and 67 (35\%) of controls experience prolonged labor during the last pregnancy. Of the infants' mothers, 45 (23\%) of cases and 27 (14\%) of controls faced premature rupture of membrane before labor starts. Only 17 $(9 \%)$ of cases and $12(6 \%)$ of controls faced prolonged rupture of membrane after 24 hours. Very few study subjects, $11(6 \%)$ of cases and $4(2 \%)$ of controls, faced cord prolapse. Twelve (13\%) of cases and $7(4 \%)$ of controls had breech presentation. Of the total subjects, $53(28 \%)$ of cases and $61(32 \%)$ of controls were delivered with cesarean section, and $38(20 \%)$ of cases and $15(8 \%)$ of controls were delivered with instrumental assisted. Few respondents, $30(16 \%)$ of cases and 5 (3\%) of controls, delivered at health centers (Table 3).

\section{Newborn Characteristics}

Of the total newborns, 117 (61\%) of cases and 104 (54\%) of controls were males. Among all sexes, 65 (35\%) of cases and $10(5 \%)$ of controls had low birth weight. Preterm babies contributed $32(17 \%)$ of cases and $5(3 \%)$ of controls. In cross-tabulation with birth weight, preterm babies contributed $34 \%$ of low birth weight. One hundred forty-six (76\%) of cases were unable to breath after birth, however, only 31 (16\%) of cases experienced spasm. The majority, 189 (98\%) of cases were unable to suckle normally after birth, and 184 $(95 \%)$ of cases were unable to cry after birth (Table 4).

\section{Determinants of Birth Asphyxia}

As per the experts' recommendation, many variables were selected for the study to exhaust potential covariates of birth asphyxia. In binary logistic regression analysis, 27 variables were entered in the analysis and only 20 variables were identified as determinants of birth asphyxia (Table 5). The other theme of variables were not associated with birth asphyxia. Variables that have $p<0.2$ in the bivariate analysis and enter to multivariable analysis were; maternal marital status, place of residence, occupation, education, distance from the hospitals, bleeding during pregnancy, iron-deficiency anemia, referral status, gravidity, multiple births, number of ANC visits, prolonged labor, premature rupture of membrane, cord prolapse, fetal presentation, mode of delivery, place of delivery, gestational age, sex of newborn, and birth weight. After adjustment, the determinants that have $p<0.05$ at $95 \% \mathrm{CI}$ are only prolonged labor, mode of delivery, place of delivery, and birth weight (Table 5).

Newborns born from mothers with prolonged labor were twice as likely to suffer from birth asphyxia as compared to their counterparts (AOR: $2.00,95 \% \mathrm{CI}: 1.20$, 3.36). Newborns that were born using instrumental delivery were 3.03 times more likely to develop birth asphyxia than those delivered by vaginally (AOR: 3.03, 95\%CI: $1.41,6.49)$. Newborns that were born at health centers were 7.36 times more likely to develop birth asphyxia than those born at hospitals (AOR: 7.36, 95\% CI: 2.44, 22.13). Newborns with low birth weight $(2.5 \mathrm{~kg})$ had 8.94 higher odds of birth asphyxia than those of normal $(\geq 2.5 \mathrm{~kg})$ at birth (AOR: $8.94,95 \% \mathrm{CI}: 4.08,19.56$ ) (Table 5). 
Table I Sociodemographic and Behavioral Characteristics of Respondents Among Newborns of Amhara Region Referral Hospitals, Ethiopia, 2018

\begin{tabular}{|c|c|c|c|c|}
\hline Variables & $\begin{array}{l}\text { Cases }(\%) \\
(n=193)\end{array}$ & $\begin{array}{l}\text { Controls (\%) } \\
(n=193)\end{array}$ & $\begin{array}{l}\text { Total Count }(\%) \\
(n=386)\end{array}$ & $\begin{array}{l}\text { Chi-Squared ( } p \text { - } \\
\text { value) }\end{array}$ \\
\hline \multicolumn{5}{|l|}{ Maternal age (in years) } \\
\hline $15-24$ & $63(32.6)$ & $67(34.7)$ & $130(33.7)$ & $0.198(0.906)$ \\
\hline $25-34$ & $109(56.5)$ & $105(54.4)$ & $214(55.4)$ & \\
\hline $35-49$ & $21(10.9)$ & $21(10.9)$ & $42(10.9)$ & \\
\hline \multicolumn{5}{|l|}{ Marital status } \\
\hline Unmarried & $\mathrm{II}(5.7)$ & $23(11.9)$ & $34(8.8)$ & $4.644(0.031)$ \\
\hline Married & $182(94.3)$ & $170(88.1)$ & $352(9 \mid .2)$ & \\
\hline \multicolumn{5}{|l|}{ Place of residence } \\
\hline Urban & $103(53.4)$ & $12 \mid(62.7)$ & $224(58)$ & $3.446(0.063)$ \\
\hline Rural & $90(46.6)$ & $72(37.3)$ & $162(42)$ & \\
\hline \multicolumn{5}{|l|}{ Maternal occupation } \\
\hline Laborer and student & $15(7.8)$ & $28(14.5)$ & $43(11.1)$ & $12.26 \mid(0.016)$ \\
\hline Farmer & $47(24.4)$ & $33(17.1)$ & $80(20.7)$ & \\
\hline Merchant & $22(11.4)$ & $27(14.0)$ & $49(12.7)$ & \\
\hline Housewife & $86(44.6)$ & $68(35.2)$ & $154(39.9)$ & \\
\hline Government employed & $23(11.9)$ & 37 (19.2) & $60(15.5)$ & \\
\hline \multicolumn{5}{|l|}{ Educational status } \\
\hline Unable to read and write & $49(25.4)$ & $39(20.2)$ & $88(22.8)$ & $9.694(0.046)$ \\
\hline Able to read and write with & $17(8.8)$ & $12(6.2)$ & $29(7.5)$ & \\
\hline \multicolumn{5}{|l|}{ informal education $^{\mathrm{a}}$} \\
\hline Elementary school (I-8 grades) & $63(32.6)$ & $53(27.5)$ & $116(30.1)$ & \\
\hline High school and Prep (9-12 grades) & $39(20.2)$ & $42(21.8)$ & $81(21.0)$ & \\
\hline Above 12 grades & $25(13.0)$ & $47(24.4)$ & $72(18.7)$ & \\
\hline \multicolumn{5}{|l|}{ Monthly income (average in ETB) } \\
\hline$\leq 2000$ & II $3(58.5)$ & $95(49.2)$ & $208(53.9)$ & $3.384(0.184)$ \\
\hline $200 I-5000$ & $60(31.1)$ & $73(37.8)$ & $133(34.5)$ & \\
\hline$>5000$ & $20(10.4)$ & $25(13.0)$ & $45(11.7)$ & \\
\hline \multicolumn{5}{|l|}{ Distance from the hospital (in km) } \\
\hline $0-10$ & $78(40.4)$ & $108(56.0)$ & $186(48.2)$ & $|2.44|(0.002)$ \\
\hline $11-50$ & $70(36.3)$ & $62(32.1)$ & $132(34.2)$ & \\
\hline $5 I-275$ & $45(23.3)$ & $23(11.9)$ & $68(17.6)$ & \\
\hline \multicolumn{5}{|l|}{ Khat chewing } \\
\hline No & $187(96.9)$ & $187(96.9)$ & $374(96.9)$ & b \\
\hline Yes & $6(3.1)$ & $6(3.1)$ & $12(3.1)$ & \\
\hline \multicolumn{5}{|l|}{ Alcohol drinking } \\
\hline No & $13 \mid(67.9)$ & $128(66.3)$ & $259(67.1)$ & $0.106(0.745)$ \\
\hline Yes & $62(32.1)$ & $65(33.7)$ & $127(32.9)$ & \\
\hline
\end{tabular}

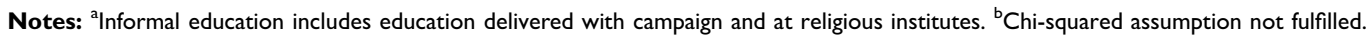

\section{Discussion}

This study identified significant determinants of birth asphyxia in Referral Hospitals of Amhara National Regional State, Ethiopia. Some of intra-partum and newborn-related variables were associated to birth asphyxia. Prolonged labor, instrumental delivery (using forceps and vacuum extraction), place of delivery (at health centers), and low birth weight were identified as significant determinants of neonatal birth asphyxia.

This finding shows that prolonged labor is statistically significant determinant of birth asphyxia. It is in line with a cross-sectional study done in Jimma zone of Ethiopia. ${ }^{11}$ Other previous studies have also shown similar results. ${ }^{25,26}$ 
Table 2 Maternal Health Related Variables Among Newborns of Amhara Region Referral Hospitals, Ethiopia, 2018

\begin{tabular}{|c|c|c|c|c|}
\hline Variables & Cases $(\%)(n=193)$ & Controls (\%) $(n=193)$ & Total Count (\%) $(n=386)$ & Chi-Squared ( $p$-value) \\
\hline \multicolumn{5}{|l|}{ Preeclampsia/eclampsia } \\
\hline No & $173(89.6)$ & I77 (9I.7) & $350(90.7)$ & $0.490(0.484)$ \\
\hline Yes & $20(10.4)$ & $16(8.3)$ & $36(9.3)$ & *merge this cell with above cell \\
\hline \multicolumn{5}{|l|}{ HIV status } \\
\hline No & $185(95.9)$ & I84 (95.3) & $369(95.6)$ & $0.062(0.804)$ \\
\hline Yes & $8(4.1)$ & $9(4.7)$ & $17(4.4)$ & *merge this cell with above cell \\
\hline \multicolumn{5}{|l|}{ Diabetes Mellitus } \\
\hline No & I9I (99.0) & $192(99.5)$ & $383(99.2)$ & a \\
\hline Yes & $2(1.0)$ & $\mathrm{I}(0.5)$ & $3(0.8)$ & \\
\hline \multicolumn{5}{|l|}{ Bleeding in pregnancy (APH) } \\
\hline No & |7| (88.6) & $179(92.7)$ & $350(90.7)$ & $1.961(0.161)$ \\
\hline Yes & $22(9.3)$ & $14(7.3)$ & $36(9.3)$ & \\
\hline \multicolumn{5}{|l|}{ Iron-deficiency anemia } \\
\hline No & $149(77.2)$ & $161(83.4)$ & $310(80.3)$ & $2.359(0.125)$ \\
\hline Yes & $44(22.8)$ & $32(16.6)$ & $76(19.7)$ & \\
\hline \multicolumn{5}{|l|}{ Referral status } \\
\hline No & $69(35.8)$ & $104(53.9)$ & $173(44.8)$ & $12.832(0.000)$ \\
\hline Yes & $124(64.2)$ & $89(46.1)$ & $213(55.2)$ & \\
\hline
\end{tabular}

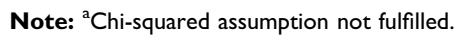

Women with a prolonged labor had a negative birth experience more often than did women who had a normal labor. ${ }^{27}$ According to American Pregnancy Association and Reiter and Walsh, PC, prolonged labor or failure to progress occurs when labor lasts for approximately $20 \mathrm{~h}$ or more if you are a first-time mother, and $14 \mathrm{~h}$ or more if you have previously given birth. A prolonged latent phase happens during the first stage of labor. It can be exhausting and emotionally draining, but rarely leads to complications. Prolonged labor may happen due to slow effacement of the cervix, too large baby, too small birthing canal or woman's pelvis, carrying multiples, incorrect fetal presentation, psychological factors, such as worry, stress, or fear. $^{28,29}$

Our study result shows that instrumental delivery determined the occurrence of neonatal birth asphyxia. This in agreement with a case-control study done in India ${ }^{30}$ and cross-section findings in Ethiopia $^{31}$ and Pakistan. ${ }^{32} \mathrm{~A}$ research conducted in England revealed that infants born by instrumental assisted delivery (forceps and vacuum extraction) for presumed fetal compromise had the poorest condition at birth. ${ }^{33}$ Infants delivered by instrumental assisted had the worst neonatal effects, suggesting the mode of delivery itself is influential. ${ }^{33}$ Instrumental delivery is permitted when spontaneous vaginal delivery is failed. In Ethiopia, both instruments are acceptable in delivery, however, forceps assisted delivery is permitted for high level professionals. It is, therefore, the practitioners may delay to practice after the rupture of membrane and the newborn may come to asphyxia.

The study shows that neonates born at health centers had higher risk of birth asphyxia than those who were born at hospitals. In many scholars, place of delivery, in general, has an association with birth asphyxia. ${ }^{10,18,34}$ In Ethiopia setting, health centers are belonging to primary health care level, whereas, referral hospitals are belonging to tertiary health care level. The health care level in the two settings are different in that cases in health centers setup may not get skilled birth attendants, however, it is not true for referral hospitals. In this study, it was impossible to get similar studies for comparison between the health centers and hospitals; however, there might be different causes of asphyxia when born in health centers, such as lack of skilled birth attendants, and/or delay to refer the cases to hospitals, and/or transportation issues.

This finding shows that neonates with low birth weight had higher risk of asphyxia than those with normal birth weight. Other studies in Thailand, Pakistan, and Iran also revealed similar results. ${ }^{14,18,21}$ Low birth weight is mostly indicated as a fetal risk factor. The primary cause of low 
Table 3 Antepartum and Intrapartum Characteristics of Respondents Among Newborns of Amhara Region Referral Hospitals, Ethiopia, 2018

\begin{tabular}{|c|c|c|c|c|}
\hline Variables & $\begin{array}{l}\text { Cases (\%) } \\
(n=193)\end{array}$ & $\begin{array}{l}\text { Controls (\%) } \\
(n=193)\end{array}$ & $\begin{array}{l}\text { Total Count }(\%) \\
(n=386)\end{array}$ & $\begin{array}{l}\text { Chi-Squared ( } p \text { - } \\
\text { value) }\end{array}$ \\
\hline \multicolumn{5}{|l|}{ Gravidity } \\
\hline Primigravida & $102(52.8)$ & $88(45.6)$ & $190(49.2)$ & $2.032(0.154)$ \\
\hline Multigravida & 91 (47.2) & $105(54.4)$ & $196(50.8)$ & \\
\hline \multicolumn{5}{|l|}{ Parity } \\
\hline Primiparous & $109(56.5)$ & $97(50.3)$ & $206(53.4)$ & $\mathrm{I} .499(0.22 \mathrm{I})$ \\
\hline Multiparous & $84(43.5)$ & $96(49.7)$ & $180(46.6)$ & \\
\hline \multicolumn{5}{|l|}{ Fetal outcome } \\
\hline Single & I77 (9|.7) & $188(97.4)$ & $365(94.6)$ & $6.093(0.014)$ \\
\hline Twins & $16(8.3)$ & $5(2.6)$ & $21(5.4)$ & \\
\hline \multicolumn{5}{|l|}{ Number of ANC visits } \\
\hline 0 & $4(2.1)$ & $5(2.6)$ & $9(2.3)$ & $7.579(0.023)$ \\
\hline $1-3$ & $105(54.4)$ & $78(40.4)$ & $183(47.4)$ & \\
\hline$\geq 4$ & $84(43.5)$ & $110(57.0)$ & $194(50.3)$ & \\
\hline \multicolumn{5}{|l|}{ Place of ANC visits } \\
\hline $\begin{array}{l}\text { Private and NonGovernmental Organization's } \\
\text { health facility }\end{array}$ & $29(15.3)$ & $28(14.9)$ & & $0.129(0.938)$ \\
\hline Public health facility & $160(84.7)$ & $160(85.1)$ & 320 (84.9) & \\
\hline \multicolumn{5}{|l|}{ Prolonged labor } \\
\hline No & $105(54.4)$ & $126(65.3)$ & $231(59.8)$ & $4.754(0.029)$ \\
\hline Yes & $88(45.5)$ & $67(34.7)$ & $145(40.2)$ & \\
\hline \multicolumn{5}{|l|}{ Premature rupture of membrane } \\
\hline No & I 48 (76.7) & $166(86.0)$ & $314(8 \mid .3)$ & $5.532(0.019)$ \\
\hline Yes & $45(23.3)$ & $27(14.0)$ & $72(18.7)$ & \\
\hline \multicolumn{5}{|l|}{ Prolonged rupture of membrane } \\
\hline No & $176(9 \mid .2)$ & I8I (93.8) & $357(92.5)$ & $0.932(0.334)$ \\
\hline Yes & $17(8.8)$ & $12(6.2)$ & $29(7.5)$ & \\
\hline \multicolumn{5}{|l|}{ Cord prolapse } \\
\hline No & I $82(94.3)$ & $189(97.9)$ & $371(96.1)$ & $3.399(0.065)$ \\
\hline Yes & II (5.7) & $4(2.1)$ & $15(3.9)$ & \\
\hline \multicolumn{5}{|l|}{ Presentation } \\
\hline Cephalic & $168(87.0)$ & $186(94.4)$ & 354 (9l.7) & II $.040(0.001)$ \\
\hline Breech & $25(13.0)$ & $7(3.6)$ & $32(8.3)$ & \\
\hline \multicolumn{5}{|l|}{ Mode of delivery } \\
\hline Vaginally & $102(52.8)$ & $117(60.6)$ & $219(56.7)$ & $1 \mathrm{I} .570(0.003)$ \\
\hline Cesarean section & $53(27.5)$ & $61(31.6)$ & II4 (29.5) & \\
\hline Instrumental (vacuum extraction and forceps) & $38(19.7)$ & $15(7.8)$ & $53(13.7)$ & \\
\hline \multicolumn{5}{|l|}{ Place of delivery } \\
\hline Health center & $30(15.5)$ & $5(2.6)$ & $35(9.1)$ & $19.638(0.000)$ \\
\hline Hospital & $163(84.5)$ & $188(97.4)$ & $351(90.9)$ & \\
\hline
\end{tabular}

birth weight is premature birth (being born before 37 weeks gestation), as it is true for our finding, $10 \%$ of neonates were preterm. Another causes of low birth weight is intrauterine growth restriction, maternal health issues, early maternal age, and multiple births. ${ }^{35}$ Low birth weight neonates should to be given much more attention 
Table 4 Newborn Characteristics Among Newborns of Amhara Region Referral Hospitals, Ethiopia, 2018

\begin{tabular}{|c|c|c|c|c|}
\hline Variables & Cases $(\%)(n=193)$ & Controls (\%) $(n=193)$ & Total Count (\%) $(n=386)$ & Chi-Squared ( $p$-value) \\
\hline \multicolumn{5}{|l|}{ Sex of newborn } \\
\hline Male & $117(60.6)$ & $104(53.9)$ & $221(57.3)$ & $\mathrm{I} .789(0.18 \mathrm{I})$ \\
\hline Female & $76(39.4)$ & $89(46.1)$ & $165(42.7)$ & \\
\hline \multicolumn{5}{|l|}{ Birth weight } \\
\hline Low birth weight $(<2.5 \mathrm{~kg})$ & $67(34.7)$ & $10(5.2)$ & $77(19.9)$ & $52.709(0.000)$ \\
\hline Normal ( $\geq 2.5 \mathrm{~kg})$ & $126(65.3)$ & $183(94.8)$ & $309(80.1)$ & \\
\hline \multicolumn{5}{|l|}{ Gestational age (wks) } \\
\hline$<37$ (preterm) & $32(16.6)$ & $5(2.6)$ & $37(9.6)$ & $21.820(0.000)$ \\
\hline $37-41$ (term) & $150(77.7)$ & $176(9 \mid .2)$ & $326(84.5)$ & \\
\hline$>4$ I (Post-term) & II (5.7) & $12(6.2)$ & $23(6.0)$ & \\
\hline \multicolumn{5}{|l|}{ Able to breath after birth } \\
\hline No & $146(75.6)$ & $0(0.0)$ & I46 (37.8) & a \\
\hline Yes & $47(24.4)$ & $193(100)$ & $240(62.2)$ & \\
\hline \multicolumn{5}{|l|}{ Had convulsions/spasm } \\
\hline No & $162(83.9)$ & $193(100)$ & $355(92.0)$ & a \\
\hline Yes & $31(16.1)$ & $0(0.0)$ & $31(8.0)$ & \\
\hline \multicolumn{5}{|l|}{ Able to suckle normally after birth } \\
\hline No & $189(97.9)$ & $0(0.0)$ & $189(49.0)$ & a \\
\hline Yes & $4(2.1)$ & $193(100)$ & $197(5 \mathrm{I} .0)$ & \\
\hline \multicolumn{5}{|l|}{ Able to cry after birth } \\
\hline No & $184(95.3)$ & $0(0.0)$ & $184(47.7)$ & a \\
\hline Yes & $9(4.7)$ & $193(100)$ & $202(52.3)$ & \\
\hline \multicolumn{5}{|l|}{ APGAR Score } \\
\hline Severe $(0-3)$ & $13(6.7)$ & $0(0.0)$ & I3 (3.4) & a \\
\hline Mild to moderate (4-6) & $180(93.3)$ & $0(0.0)$ & $180(46.6)$ & \\
\hline Normal (7-10) & $0(0.0)$ & $193(100)$ & $193(50.0)$ & \\
\hline
\end{tabular}

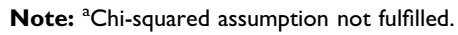

compared to their counterparts whose birth weight are normal as they are prone to asphyxia. ${ }^{36}$ In general, the findings of this study will provide additional information on the current clinical knowledge.

This study has strength in that the study was done at region level on five referral hospitals, which may reflect regional burden at hospital levels. There are limitations of the study as it is hospital based study where majority of births were attended by qualified personnel. Consequently, it does not reflect exact risk factors prevalent in the community, where majority of births are unable to access those referral hospitals. The findings of the study are particular to those infants who either have access to NICU services or survived for long enough to reach the NICU. Also, because a person is assigning the number, the APGAR score is subjective that may under or overestimate the magnitude of birth asphyxia.

\section{Conclusions}

This study identified determinants of neonatal birth asphyxia in Referral Hospitals of Amhara National Regional State, Ethiopia. Prolonged labor/failure to progress, mode of delivery (instrumental), place of delivery (at health centers), and low birth weight were identified as statistically significant determinants of birth asphyxia. Even though most of the identified variables are the common and familiar causes of birth asphyxia, neonates born at health centers were more exposed to birth asphyxia than neonates born in hospitals. This might be due to delay of referral process and lack of skilled professionals in health centers. Consequently, it may indicate the need of operational intervention planning and further researches. This study will inform health care providers especially at health centers for their appropriate interventions and it may even need managerial decisions for improving referral systems to make fast to reduce 
Table 5 Determinants of Birth Asphyxia Among Newborns of Amhara Region Referral Hospitals, Ethiopia, 2018

\begin{tabular}{|c|c|c|c|c|}
\hline \multirow{2}{*}{ Variables } & \multirow[t]{2}{*}{ Controls } & \multirow[t]{2}{*}{ Cases } & \multicolumn{2}{|c|}{ Crudes and Adjusted Odds Ratios with $95 \%$ Confidence Intervals } \\
\hline & & & COR $(95 \% \mathrm{Cl})$ & AOR (95\%Cl) \\
\hline \multicolumn{5}{|l|}{ Marital status } \\
\hline Unmarried & 23 & II & 1 & I \\
\hline Married & 170 & 182 & $2.24(1.06,4.73)$ & $1.79(0.7 \mathrm{I}, 4.47)$ \\
\hline \multicolumn{5}{|l|}{ Place of residence } \\
\hline Urban & 121 & 103 & 1 & 1 \\
\hline Rural & 72 & 90 & $1.47(0.98,2.21)$ & $0.78(0.36,1.66)$ \\
\hline \multicolumn{5}{|l|}{ Maternal occupation } \\
\hline Laborer and student & 28 & 15 & $0.86(0.38,1.95)$ & $1.04(0.39,2.83)$ \\
\hline Farmer & 33 & 47 & $2.29(1.16,4.54)^{*}$ & $1.74(0.67,4.49)$ \\
\hline Merchant & 27 & 22 & I.3। $(0.6 \mathrm{I}, 2.82)$ & $0.90(0.33,2.42)$ \\
\hline Housewife & 68 & 86 & $2.04(1.11,3.74)^{*}$ & $1.52(0.70,3.30)$ \\
\hline Government employed & 37 & 23 & 1 & 1 \\
\hline \multicolumn{5}{|l|}{ Educational status } \\
\hline Unable to read and write & 39 & 49 & $2.36(1.24,4.49)^{*}$ & $\mathrm{I} .83(0.5 \mathrm{I}, 6.59)$ \\
\hline Able to read and write & 12 & 17 & $2.66(1.10,6.45)^{*}$ & $2.07(0.5 \mathrm{I}, 8.42)$ \\
\hline Elementary school (I-8 grades) & 53 & 63 & $2.24(1.22,4.10)^{*}$ & $1.73(0.57,5.27)$ \\
\hline High school and Prep(9-12 grades) & 42 & 39 & $1.75(0.91,3.35)$ & $1.78(0.62,5.14)$ \\
\hline Above 12 grades & 47 & 25 & 1 & 1 \\
\hline \multicolumn{5}{|l|}{ Distance from the hospital (in km) } \\
\hline $0-10$ & 108 & 78 & 1 & 1 \\
\hline II-50 & 62 & 20 & $1.56(0.99,2.45)$ & $0.74(0.39,1.39)$ \\
\hline $51-275$ & 23 & 45 & $2.71(1.52,4.84)^{*}$ & $1.69(0.78,3.65)$ \\
\hline \multicolumn{5}{|l|}{ Bleeding in pregnancy (APH) } \\
\hline No & 179 & $17 \mid$ & 1 & I \\
\hline Yes & 14 & 22 & $1.65(0.82,3.32)$ & $\mathrm{I} .24(0.5 \mathrm{I}, 3.0 \mathrm{I})$ \\
\hline \multicolumn{5}{|l|}{ Iron-deficiency anemia } \\
\hline No & 161 & 149 & I & I \\
\hline Yes & 32 & 44 & $1.49(0.90,2.47)$ & $1.29(0.68,2.44)$ \\
\hline \multicolumn{5}{|l|}{ Referral status } \\
\hline No & 104 & 69 & I & I \\
\hline Yes & 89 & 124 & $2.10(1.40,3.16)^{*}$ & $1.72(0.95,3.11)$ \\
\hline \multicolumn{5}{|l|}{ Gravidity } \\
\hline Primigravida & 88 & 102 & 1 & 1 \\
\hline Multigravida & 105 & 91 & $0.75(0.50,1.12)$ & $0.83(0.48,1.42)$ \\
\hline \multicolumn{5}{|l|}{ Fetal outcome } \\
\hline Single & 188 & 177 & 1 & 1 \\
\hline Twins & 5 & 16 & $3.40(1.22,9.47)^{*}$ & $1.90(0.5 \mathrm{I}, 7.15)$ \\
\hline \multicolumn{5}{|l|}{ Number of ANC visits } \\
\hline 0 & 5 & 4 & $\mathrm{I} .05(0.27,4.02)$ & $0.22(0.04,1.15)$ \\
\hline $1-3$ & 78 & 105 & $1.76(1.17,2.65)^{*}$ & $1.34(0.8 \mathrm{I}, 2.2 \mathrm{I})$ \\
\hline$\geq 4$ & 110 & 84 & 1 & I \\
\hline \multicolumn{5}{|l|}{ Prolonged labor } \\
\hline No & 126 & 105 & 1 & I \\
\hline Yes & 67 & 88 & $1.58(1.05,2.38)^{*}$ & $2.00(1.20,3.36)^{* *}$ \\
\hline
\end{tabular}

(Continued) 
Table 5 (Continued).

\begin{tabular}{|c|c|c|c|c|}
\hline \multirow[t]{2}{*}{ Variables } & \multirow[t]{2}{*}{ Controls } & \multirow[t]{2}{*}{ Cases } & \multicolumn{2}{|c|}{ Crudes and Adjusted Odds Ratios with $95 \%$ Confidence Intervals } \\
\hline & & & COR $(95 \% \mathrm{Cl})$ & AOR $(95 \% \mathrm{Cl})$ \\
\hline \multicolumn{5}{|l|}{ Premature rupture of membrane } \\
\hline No & 166 & 148 & 1 & 1 \\
\hline Yes & 27 & 45 & $1.87(1.11,3.16)^{*}$ & $1.55(0.82,2.95)$ \\
\hline \multicolumn{5}{|l|}{ Cord prolapse } \\
\hline No & 189 & 182 & I & 1 \\
\hline Yes & 4 & 11 & $2.86(0.89,9.13)$ & $3.4 \mathrm{I}(0.86,13.46)$ \\
\hline \multicolumn{5}{|l|}{ Presentation } \\
\hline Cephalic & 186 & 168 & I & 1 \\
\hline Breech & 7 & 25 & $3.95(1.67,9.38)^{*}$ & $2.71(0.96,7.70)$ \\
\hline \multicolumn{5}{|l|}{ Mode of delivery } \\
\hline Spontaneous vaginal delivery (SVD) & 117 & 102 & I & I \\
\hline Cesarean section & 61 & 53 & $0.99(0.63,1.57)$ & $0.96(0.55,1.67)$ \\
\hline Instrumental & 15 & 38 & $2.91(I .5 I, 5.59)^{*}$ & $3.03(\mathrm{I} .4 \mathrm{I}, 6.49)^{* *}$ \\
\hline \multicolumn{5}{|l|}{ Place of delivery } \\
\hline Health center & 5 & 30 & $6.92(2.62,18.25)^{*}$ & $7.36(2.44,22.13)^{* * *}$ \\
\hline Hospital & 188 & 163 & 1 & I \\
\hline \multicolumn{5}{|l|}{ Sex of newborn } \\
\hline Male & 104 & 117 & 1 & I \\
\hline Female & 89 & 76 & $0.76(0.5 \mathrm{I}, 1.14)$ & $0.79(0.48,1.30)$ \\
\hline \multicolumn{5}{|l|}{ Birth weight } \\
\hline Low birth weight $(<2.5 \mathrm{~kg})$ & 10 & 67 & $9.73(4.82,19.64)^{*}$ & $8.94(4.08,19.56)^{* * *}$ \\
\hline Normal ( $\geq 2.5$ kg) & 183 & 126 & 1 & I \\
\hline \multicolumn{5}{|l|}{ Gestational age (weeks) } \\
\hline$<37$ (Preterm) & 5 & 32 & $6.98(2.00,24.32)^{*}$ & $4.02(0.89,18.13)$ \\
\hline 37-4I(Term) & 176 & 150 & $0.93(0.40,2.17)$ & $0.70(0.26,1.93)$ \\
\hline >4I (Post-term) & 12 & II & 1 & 1 \\
\hline
\end{tabular}

Notes: ${ }^{*} p<0.20$; ${ }^{* *} p<0.01$; ${ }^{* * *} p<0.001$.

the burden of birth asphyxia occurring at primary health care level. Further researches may be recommended to identify why neonatal birth asphyxia is high at health centers rather than hospitals.

\section{Abbreviations}

APGAR, Appearance Pulse Grimace Activity Respiration; NICU, Neonatal Intensive Care Unit; CI, Confidence Interval; AOR, Adjusted odds ratio; OR, Odds ratio; P, Prevalence; ANC, Ante natal care.

\section{Acknowledgments}

We are very grateful to Bahir Dar University for the approval of the ethical clearance. We would also like to thank all individuals participated in this study for their cooperation in taking part in this study.

\section{Author Contributions}

All authors (AD, MA, EW, and GG) have substantial contributions to conception and design, acquisition of data, analysis and interpretation of data; drafting the article and revising it critically for important intellectual content; final approval of the version to be published; and agreement to be accountable for all aspects of the work in ensuring that questions related to the accuracy or integrity of any part of the work are appropriately investigated and resolved. 


\section{Disclosure}

The authors report no conflicts of interest in this work.

\section{References}

1. Antonucci R, Porcella A, Pilloni MD. Perinatal asphyxia in the term newborn. J Pediatr Neonatal Individual Med. 2014;3:2.

2. Diaz-Rosello J, Gisore P, Niermeyer S, et al. Guidelines on Basic Newborn Resuscitation 2012. Geneva: World Health Organization; 2012.

3. Tesfahun F, Worku W, Mazengiya F, Kifle M. Knowledge, perception and utilization of postnatal care of mothers in Gondar Zuria District, Ethiopia: a cross-sectional study. Matern Child Health J. 2014;18:2341-2351. doi:10.1007/s10995-014-1474-3

4. Wallander JL, McClure E, Biasini F, et al. Brain research to ameliorate impaired neurodevelopment-home-based intervention trial (BRAIN-HIT). BMC Pediatr. 2010;10(1):27. doi:10.1186/14712431-10-27

5. UNICEF. Neonatal mortality. 2019. Available from: https://data.uni cef.org/topic/child-survival/neonatal-mortality/. Accessed November $5,2019$.

6. World Health Organization. Newborn death and illness 2011. Available from: http://www.who.int/pmnch/media/press_materials/fs/ fs newborndealth_illness/en/. Accessed November 05, 2019.

7. United Nations Inter-agency Group for Child Mortality Estimation (UN IGME). Levels and Trends in Child Mortality: Report 2019, Estimates developed by the United Nations Inter-agency Group for Child Mortality Estimation. New York: United Nations Children's Fund; 2019.

8. Hug L, Alexander M, You D, Alkema L; for Child UI-aG. National, regional, and global levels and trends in neonatal mortality between 1990 and 2017, with scenario-based projections to 2030: a systematic analysis. The Lancet Global Health. 2019;7(6):e710-e20.

9. Torres-Muñoz J, Rojas C, Mendoza-Urbano D, Marín-Cuero D, Orobio S, Echandía C. Risk factors associated with the development of perinatal asphyxia in neonates at the Hospital Universitario del Valle, Cali, Colombia, 2010-2011. Biomédica. 2017;37:51-56. doi:10.7705/biomedica.v37i1.2844

10. Ilah BG, Aminu MS, Musa A, Adelakun MB, Adeniji AO, Kolawolen T. Prevalence and risk factors for Perinatal Asphyxia as seen at a specialist Hospital in Gusau, Nigeria. Sub-Saharan Afr $J$ Med. 2015;2:2.

11. Belachew T, Joseph J. Birth asphyxia and associated factors among newborns delivered in Jimma zone public hospitals, Southwest Ethiopia: a cross-sectional study. $J$ Midwifery Reprod Health. 2018;6(2):1289-1295.

12. Lawn JE, Kinney MV, Black RE, et al. Newborn survival: a multicountry analysis of a decade of change. Health Policy Plan. 2012;27 (suppl_3):iii6-iii28. doi:10.1093/heapol/czs053

13. Federal Ministry of Health, Ethiopia. National Strategy for Newborn and Child Survival in Ethiopia. 2015/16-2019/20. Maternal and Child health Directorate June 2015. Ethiopia: Addis Abeba; 2015.

14. Pitsawong C, Panichkul P. Risk factors associated with Birth Asphyxia in Phramongkutklao Hospital. Thai J Obstetr Gynaecol. 2011;19:165-171.

15. Rahim F, Jan A, Mohummad J, Iqbal H. Pattern and outcome of admissions to neonatal unit of Khyber teaching hospital, Peshawar. Pak J Med Sci. 2007;23(2):249-253.

16. Wosenu L, Worku AG, Teshome DF, Gelagay AA. Determinants of birth asphyxia among live birth newborns in University of Gondar referral hospital, northwest Ethiopia: a case-control study. PLoS ONE. 2018;13(9):e0203763. doi:10.1371/journal.pone.0203763

17. Majeed R, Memon Y, Majeed F, Shaikh NP, Rajar UD. Risk factors of birth asphyxia. J Ayub Med Coll Abbottabad. 2007;19:3.
18. Aslam HM, Saleem S, Afzal R, et al. Risk factors of birth asphyxia. Ital J Pediatr. 2014;40(1):94. doi:10.1186/s13052-014-0094-2

19. CSA E. Population Projection of Ethiopia for All Regions at Wereda Level from 2014-2017. Central Statistical Agency of Ethiopia; 2013.

20. Federal Ministry of Health, Ethiopia. Health Sector Transformation Plan 1 Version 1 Annual Performance Report EFY 2008 (2015/16); 2015.

21. Nayeri F, Shariat M, Dalili H, Adam LB, Mehrjerdi FZ, Shakeri A. Perinatal risk factors for neonatal asphyxia in Vali-e-Asr hospital, Tehran-Iran. Iran J Reprod Med. 2012;10(2):137-140.

22. Rossen J, Østborg TB, Lindtjørn E, Schulz J, Eggebø TM. Judicious use of oxytocin augmentation for the management of prolonged labor. Acta Obstet Gynecol Scand. 2016;95(3):355-361. doi:10.1111/ aogs.2016.95.issue-3

23. Cheng YW, Caughey AB. Defining and managing normal and abnormal second stage of labor. Obstetr Gynecol Clin. 2017;44(4):547566. doi:10.1016/j.ogc.2017.08.009

24. Altman M, Sandström A, Petersson G, Frisell T, Cnattingius S, Stephansson O. Prolonged second stage of labor is associated with low Apgar score. Eur J Epidemiol. 2015;30(11):1209-1215. doi:10.1007/s10654-015-0043-4

25. Chiabi A, Nguefack S, Mah E, et al. Risk factors for birth asphyxia in an urban health facility in cameroon. Iran J Child Neurol. 2013;7:3.

26. SHIREEN N, NAHAR N, MOLLAH AH. Risk factors and shortterm outcome of birth asphyxiated babies in Dhaka Medical College Hospital. Bangladesh $J$ Child Health. 2009;33(3):83-89. doi:10.3329/bjch.v33i3.5688

27. Nystedt A, Hildingsson I. Diverse definitions of prolonged labour and its consequences with sometimes subsequent inappropriate treatment. BMC Pregnancy Childbirth. 2014;14:233. doi:10.1186/1471-2393$14-233$

28. American Pregnancy Association. Prolonged labor: failure to progress; 2017. Available from: http://americanpregnancy.org/laborand-birth/prolonged-labor-failure-progress/. Accessed November 5, 2019.

29. Reiter, Walsh P. Birth asphyxia and HIE (Hypoxic-Ischemic Encephalopathy) from prolonged labor 2018. Available from: https://www.abclawcenters.com/practice-areas/prenatal-birth-injuries/ fetus-or-newborn-medical-problems/birth-asphyxia-lawyers/birthasphyxia-hypoxic-ischemic-encephalopathy-hie-often-caused-pro longed-labor/. Accessed November 05, 2019.

30. Gane B, Rao R, Nandakumar S, et al. Antenatal and intrapartum risk factors for perinatal asphyxia: a case control study. Curr Pediatr Res. 2013;17(2):119-122.

31. Ibrahim NA, Muhye A, Abdulie S. Prevalence of birth asphyxia and associated factors among neonates delivered in Dilchora Referral Hospital, in Dire Dawa, Eastern Ethiopia. Clin Mother Child Health. 2017;14:4. doi:10.4172/2090-7214

32. Kiyani AN, Khushdil A, Ehsan A. Perinatal factors leading to birth asphyxia among term newborns in a tertiary care hospital. Iran $J$ Pediatr. 2014;24(5):637-642.

33. Prior T, Kumar S. Mode of delivery has an independent impact on neonatal condition at birth. Eur J Obstetr Gynecol Reproduct Biol. 2014;181:135-139. doi:10.1016/j.ejogrb.2014.07.041

34. Darmstadt GL, Mullany LC, Katz J, Tielsch JM. Risk factors for neonatal mortality due to birth asphyxia in Southern Nepal: a prospective, community-based cohort study. NIH Public Access. 2008;121:5.

35. Stanford Children's Health. Low Birthweight; 2018. Available from: http://www.stanfordchildrens.org/en/topic/default?id=low-birth weight-90-P02382. Accessed November 05, 2019.

36. Kibai E, Victor D, J A. Perinatal risk factors associated with birth asphyxia among term neonates at county referral Hospital, Kenya. Int J Advan Res. 2017;5:7. 


\section{Publish your work in this journal}

Pediatric Health, Medicine and Therapeutics is an international, peerreviewed, open access journal publishing original research, reports, editorials, reviews and commentaries. All aspects of health maintenance, preventative measures and disease treatment interventions are addressed within the journal. Practitioners from all disciplines are invited to submit their work as well as healthcare researchers and patient support groups. The manuscript management system is completely online and includes a very quick and fair peer-review system. Visit http://www.dovepress.com/testimonials.php to read real quotes from published authors. 